\title{
Growth and Tolerance of Eucalyptus Seedlings in Soil Contaminated by Copper
}

\author{
Alex Negrini ${ }^{1}$ (1) 0000-0002-1640-2720 \\ Rodrigo Ferreira da Silva ${ }^{1}$ (1) 0000-0002-1747-2149 \\ Clovis Orlando Da Ros ${ }^{1}$ (1) 0000-0003-4514-8992 \\ Rudinei De $\mathrm{Marco}^{2}$ (1) 0000-0003-2648-0279 \\ Mateus Vanzan ${ }^{1}$ (1) 0000-0001-6916-823X
}

\begin{abstract}
Copper damages plants when present in high concentrations in the soil. This study assessed the growth and tolerance of Eucalyptus grandis, E. saligna, E. dunnii, and Corymbia citriodora seedlings in soil contaminated by copper. The experimental design was completely randomized in a factorial scheme $(4 \times 6)$, with four eucalyptus species and six copper doses $\left(0,80,160,240,320,400 \mathrm{mg} \mathrm{kg}^{-1}\right)$ with eight replications. The experiment was performed in a greenhouse for 120 days. The height, stem diameter, root dry mass and shoot dry mass, root specific surface area, Dickson quality index, and tolerance index were assessed. The results showed that the morphological parameters of the studied eucalyptus species were reduced by the copper doses added in the soil. However, the Corymbia citriodora and the Eucalyptus saligna species had a higher tolerance index to the metal.
\end{abstract}

Keywords: tree species, exotic, heavy metal.

\section{INTRODUCTION AND OBJECTIVES}

Heavy metals are found in soils, sediments, water, biological samples, and in the air, becoming potentially toxic (Dghaim et al., 2015). When in high concentrations, Copper (Cu) is one of the main heavy metals with polluting potential in soil and water (Andreazza et al., 2010). When present in the soil in high concentrations, copper may affect plant growth and development (Santos et al., 2010), as it causes disturbances in the structure of proteins and prevents cell elongation, since it increases plasma membrane permeability and cell wall lignification (Yruela, 2009).

The main cause of high concentrations of $\mathrm{Cu}$ in the soil is anthropic, because of the intensified industrial, agricultural, and urbanization activities, causing soil pollution and developing environmental impacts (Andreazza et al., 2010). Mining, together with copper fungicide applications in vineyards, significantly contribute to $\mathrm{Cu}$ soil contamination (Chaignon \& Hinsinger, 2003), as well as the continuous and intense use of heavy metals by anthropic activity (Andreazza et al., 2013).
Because of the increasing contaminated areas by $\mathrm{Cu}$, the use of technologies that reduce the toxic effects of this element is necessary. Among them, the use of plants has been an interesting alternative and seeks to use species with the potential to develop, absorb, and retain the metal in the plant tissues, consequently reducing its toxic effect in the soil.

Regarding plant species, the Eucalyptus genus encompasses more than 600 species, presents good adaptation to the Brazilian climatic conditions, with relatively fast growth and development, and large biomass production (Magalhães et al., 2011). However, studies by De Marco et al. (2017) have showed that the Eucalyptus grandis seedlings have high capacity to accumulate $\mathrm{Cu}$ in their root system, which would enable its use for phytostabilization, but there are still few studies including the use of different eucalyptus species.

Several nutritional, physiological, and biochemical processes and reactions are related to the tolerance and adaptation mechanisms used by certain plants, which enable production in areas with deficiency or excess of elements, as well as the

\footnotetext{
${ }^{1}$ Universidade Federal de Santa Maria (UFSM), Frederico Westphalen, RS, Brasil

${ }^{2}$ Universidade Federal de Pelotas (UFPel), Pelotas, RS, Brasil
} 
possibility of recovering areas with heavy metals excess (Souza et al., 2011). Thus, it is hypothesized that Eucalyptus grandis, Eucalyptus saligna, Eucalyptus dunnii, and Corymbia citriodora species differ in growth and tolerance to high copper concentrations in the soil.

Therefore, this study aimed to assess the growth and tolerance of eucalyptus species in soil contaminated by copper.

\section{MATERIALS AND METHODS}

The experiment was performed in a greenhouse belonging to the Departamento de Ciências Agronômicas e Ambientais da Universidade Federal de Santa Maria, Frederico Westphalen Campus, between October 2015 and January 2016.

The experimental design was completely randomized in factorial arrangement $(4 \times 6)$, with four forest species (Eucalyptus grandis W. Hill ex Maiden, Corymbia citriodora (Hook.) K.D. Hill \& L.A.S. Johnson, Eucalyptus saligna Smith, and Eucalyptus dunnii Maiden) and six copper doses added to the soil ( 0 - natural content of the soil -, 80, 160, 240, 320, and $\left.400 \mathrm{mg} \mathrm{kg}^{-1}\right)$, with eight repetitions.

The $\mathrm{Cu}$ doses were mixed into the soil 30 days before the seedling transplantation in the form of copper sulphate solution $\left(\mathrm{CuSO}_{4} .5 \mathrm{H}_{2} \mathrm{O}\right)$, being diluted in $50 \mathrm{~mL}$ of distilled water to allow better homogenization. Soil samples were collected for determining the pseudo-total copper contents at the time of the seedlings transplantation, according to the methodology 3050b described in USEPA (1996).

The soil used in the experiment was defined as a Red Latosol, collected in an agricultural area in the $0-20 \mathrm{~cm}$ layer, and is shown in Table 1 according to the methodology described by Mann \& Ritchie (1993) for exchangeable copper ( $\mathrm{KCl}$ extractor $0.005 \mathrm{~mol} \mathrm{~L}^{-1}$ ) and by Tedesco et al. (1995) for the other attributes.

The seeds of the eucalyptus species used in the experiment were provided by the Centro de Pesquisa em Florestas da Fundação Estadual de Pesquisa Agropecuaria (Fepagro), Santa Maria, RS unit. Sowing was carried out by hand and when the seedlings presented a pair of definitive leaves they were transplanted to polyethylene plastic bags with volumetric capacity of $1,000 \mathrm{~cm}^{3}$. Each plastic bag with its soil content and one seedling was considered one experimental unit (EU).
The experiment was performed for 120 days after transplanting the seedlings and daily irrigations were performed during this period, maintaining moisture between 70 and $80 \%$ of the field capacity. Fertilization was performed in the seedling transplant, applying $150 \mathrm{~g}$ of $\mathrm{N}$ per $\mathrm{m}^{3}$ of soil in the form of urea; $700 \mathrm{~g}$ of $\mathrm{P}_{2} \mathrm{O}_{5}$ in the form of triple superphosphate; and $100 \mathrm{~g}$ of $\mathrm{K}_{2} \mathrm{O}$ in the form of $\mathrm{KCl}$. Then, $100 \mathrm{~g}$ of $\mathrm{N}$ in the form of urea was applied as coverage and $30 \mathrm{~g}$ of $\mathrm{K}_{2} \mathrm{O}$ diluted in $10 \mathrm{~L}$ of water was applied in the form of $50 \mathrm{~mL}$ per EU. Fertilization after transplanting the seedlings was performed in three seasons: at 30 days, with application of $\mathrm{N}$ and $\mathrm{K}$; at 60 days, only $\mathrm{N}$; and at 90 days with $\mathrm{N}$ and $\mathrm{K}$, following the instructions of Gonçalves \& Benedetti (2005). The EUs rotated weekly in order to meet the designed requirements.

At the end of the experiment, shoot height $(\mathrm{H})$ was assessed with a graduated ruler from the lap of the seedling to its stem apex; the stem diameter (SD) with digital caliper; the root system dry mass (RDM) and shoot dry mass (SDM), with both separated in the seedling lap region and dried in an oven at $60 \pm 1^{\circ} \mathrm{C}$ to constant mass, weighed on an analytical balance; and the total dry mass (TDM) by the sum of RDM and SDM. Based on these variables, the specific surface area (SSA) of the roots was estimated according to the methodology of Tennant (1975) and the Dickson quality index (DQI) (Dickson et al., 1960), according to Equation 1.

$$
\mathrm{DQI}=\frac{\mathrm{TDM}}{\frac{\mathrm{H}}{\mathrm{SD}}+\frac{\mathrm{SDM}}{\mathrm{RDM}}}
$$

The tolerance index (Toi) was estimated based on the TDM at zero dose of $\mathrm{Cu}\left(\mathrm{d}_{0}\right)$ and at doses of 80 to $400 \mathrm{mg} \mathrm{kg}^{-1}\left(\mathrm{~d}_{\mathrm{n}}\right)$, according to the equation: Toi $=\left(\mathrm{TDM}_{\mathrm{dn}} /\right.$ $\operatorname{TDM}_{\mathrm{d} 0}{ }^{*} 100$, which measures the ability of seedlings to grow in environments with high contaminant concentration (Wilkins, 1978).

The results were submitted to analysis of variance, to polynomial regression analysis, and Tukey test at $5 \%$ probability of error when significant, using the procedures available in the SISVAR program (Ferreira, 2011).

Table 1. Chemical model of soil used for seedlings production of forest species.

\begin{tabular}{|c|c|c|c|c|c|c|c|c|}
\hline $\mathrm{pH}_{\text {water }}$ & $\mathrm{Ca}+\mathrm{Mg}$ & Al & $\mathbf{H}+\mathbf{A L}$ & $\mathbf{P}_{\text {(exchangeable) }}$ & $\mathbf{K}_{\text {(exchangeable) }}$ & $\mathrm{Cu}_{\text {(exchangeable) }}$ & $\mathbf{O M}$ & Clay \\
\hline $1: 1$ & \multicolumn{3}{|c|}{$\mathrm{cmol}_{\mathrm{c}} \mathrm{kg}^{-1}$} & \multicolumn{3}{|c|}{$\mathrm{mg} \mathrm{kg}^{-1}$} & \multicolumn{2}{|c|}{$\%$} \\
\hline 5.6 & 2.23 & 0.0 & 3.3 & 6.5 & 126.5 & 12.7 & 1.1 & 62.0 \\
\hline
\end{tabular}

OM: organic matter. 


\section{RESULTS AND DISCUSSION}

$\mathrm{Cu}$ levels applied to the soil increased the pseudo-total concentrations of the element linearly, reaching values above the limits established for research in agricultural areas, which is $200 \mathrm{mg} \mathrm{kg}^{-1}$ (Conama, 2009), also surpassing the VRQs (Quality Reference Values) defined by Fepam (2014), which is $203 \mathrm{mg} \mathrm{kg}^{-1}$ for soils originating from volcanic rocks of the Plateau (Planalto), as shown in Figure 1. Moreover, in the treatments that received the highest $\mathrm{Cu}$ doses $(240,320$, and $400 \mathrm{mg} \mathrm{kg}^{-1}$ ) the soil contents were higher than double the limit for research in agricultural areas, also shown in Figure 1.

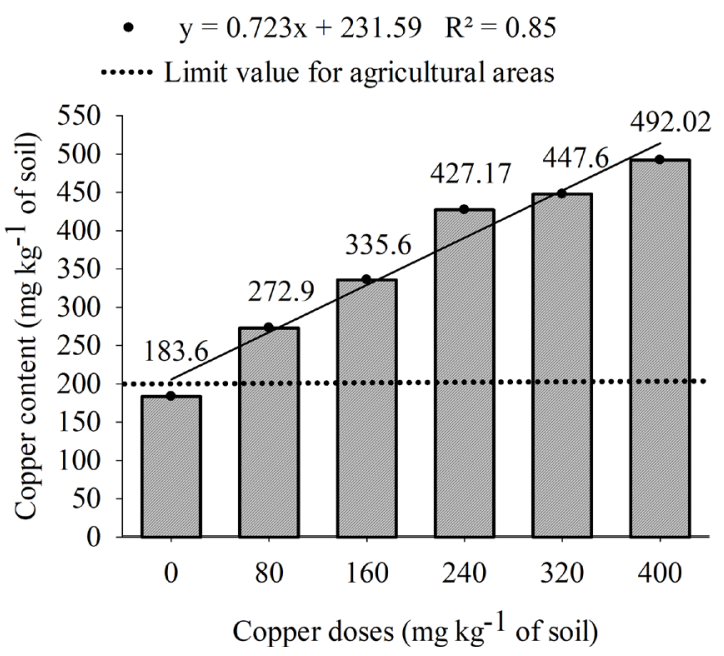

Figure 1. "Pseudo-total" copper content as a function of the $\mathrm{Cu}$ doses added to the soil.

The analysis of variance showed significant interaction $(p \leq 0.05)$ between the studied eucalyptus species and the $\mathrm{Cu}$ applied to the soil for the variables plant height, SD, RDM and SDM, root SSA, and DQI, according to Figure 2.

The $\mathrm{Cu}$ doses applied to the soil showed different effects among the species for the seedling height, since squared regression models for this factor were adjusted for C. citriodora, E. grandis and E. dunnii, and linear regression for E. saligna, as shown in Figure 2a. There was an increase in plant height only for E. grandis, with a maximum value estimated at $151.7 \mathrm{mg} \mathrm{kg}^{-1}$, showing a possible nutritional effect up to this dose with subsequent toxicity at the highest doses. According to Guo et al. (2010), Cu toxicity may be different among plant species, which can be evidenced in the eucalyptus species under study, and different responses may be observed as a result of increased Copper doses.

The stem diameter of the seedlings decreased with increasing doses of $\mathrm{Cu}$ in all species, but with lower intensity in E. saligna when comparing the higher dose with the zero dose (natural copper of the soil) showed in Figure 2b. The high $\mathrm{Cu}$ levels in the soil reduce the photosynthetic rate of plants, since they affect the electron transport chain, reducing photoassimilate production by plants, thereby reducing their growth (Kabata-Pendias, 2011). The effect showed by the difference between species can be attributed to plants developing separated tolerance mechanisms to the metal toxicity (Lequeux et al., 2010). However, the reduced SD observed in the studied eucalyptus species can be an indication that high metal contents reduce this morphological variable.

The SDM results showed a quadratic negative effect for C. citriodora and E. dunnii species, and positive quadratic behavior in E. grandis and E. saligna, with maximum efficiency (greater dry mass accumulation) at the estimated doses of 62.5 and $166.6 \mathrm{mg} \mathrm{kg}^{-1}$, respectively, as shown in Figure 2c. The positive response by E. grandis and E. saligna may be due to the nutritional effect of the micronutrient, which participates in several physiological processes of plants, and the tolerance limit is dependent on each plant species (Taiz et al., 2017).

In a study with copper doses in the Brazilian orchid tree pata-de-vaca (Bauhinia forficata) and carne-de-vaca (Pterogyne nitens) seedlings, Silva et al. (2016) found that the shoot dry mass reduction with increasing pollutant levels was significant in both native forest species, with a reduction of 72 and $74 \%$ at the maximum dose of $300 \mathrm{mg} \mathrm{kg}^{-1}$, respectively.

The RDM reduced in all studied species with the increase of the $\mathrm{Cu}$ applied to the soil, as shown in Figure 2d. The lower yields of RDM with the increase of copper doses obtained in this study corroborate the results of Silva et al. (2011), in which the root system was the first to be affected by copper in açoita-cavalo (Luehea divaricata) seedlings and Brazilian peppertree aroeira-vermelha (Schinus terebinthifolius) seedlings. However, the effect of RDM on the low doses of $\mathrm{Cu}$ in E. saligna may be related to the species tolerance to the metal through mechanisms that provide biochemical adaptations, thus allowing the plant to tolerate certain concentrations of this contaminant (Taiz et al., 2017).

E. dunnii and E. grandis species showed a linear reduction in the root SSA with increasing $\mathrm{Cu}$ doses. C. citriodora showed a quadratic reduction with a minimum estimated dose point of $344.0 \mathrm{mg} \mathrm{kg}^{-1}$, while E. saligna had a maximum dose point of $142.5 \mathrm{mg} \mathrm{kg}^{-1}$ according to Figure 2e. The reduction in root growth is one of the most evident symptoms of copper's toxic effect (Kukkola et al., 2000), because the excess micronutrient reduces the longitudinal root growth because of the contaminant chemical barriers, providing greater secondary root emission (Taiz et al., 2017). It is possible that there has been a higher production of secondary roots in E. grandis seedlings, which is interesting because it increases the water and soil nutrients absorption area. 
$\times$ Corymbia citriodora

\ Eucalyptus dunnii
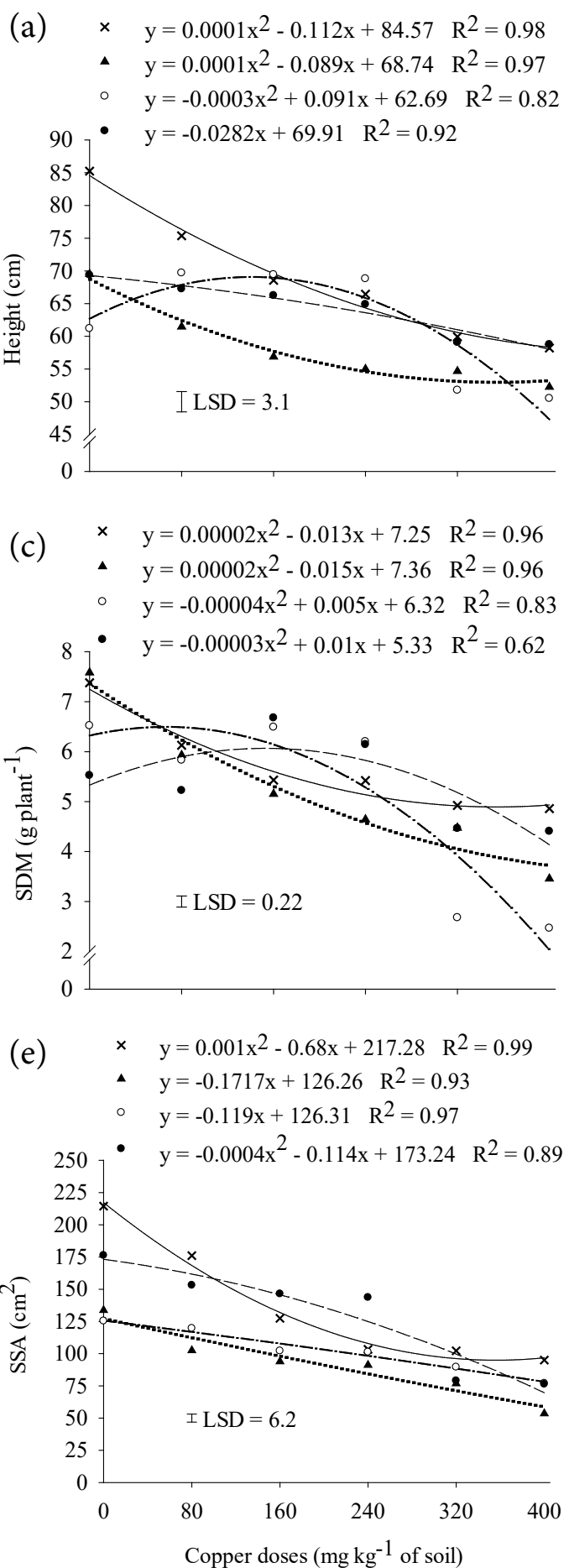

- Eucalyptus grandis

- Eucalyptus saligna
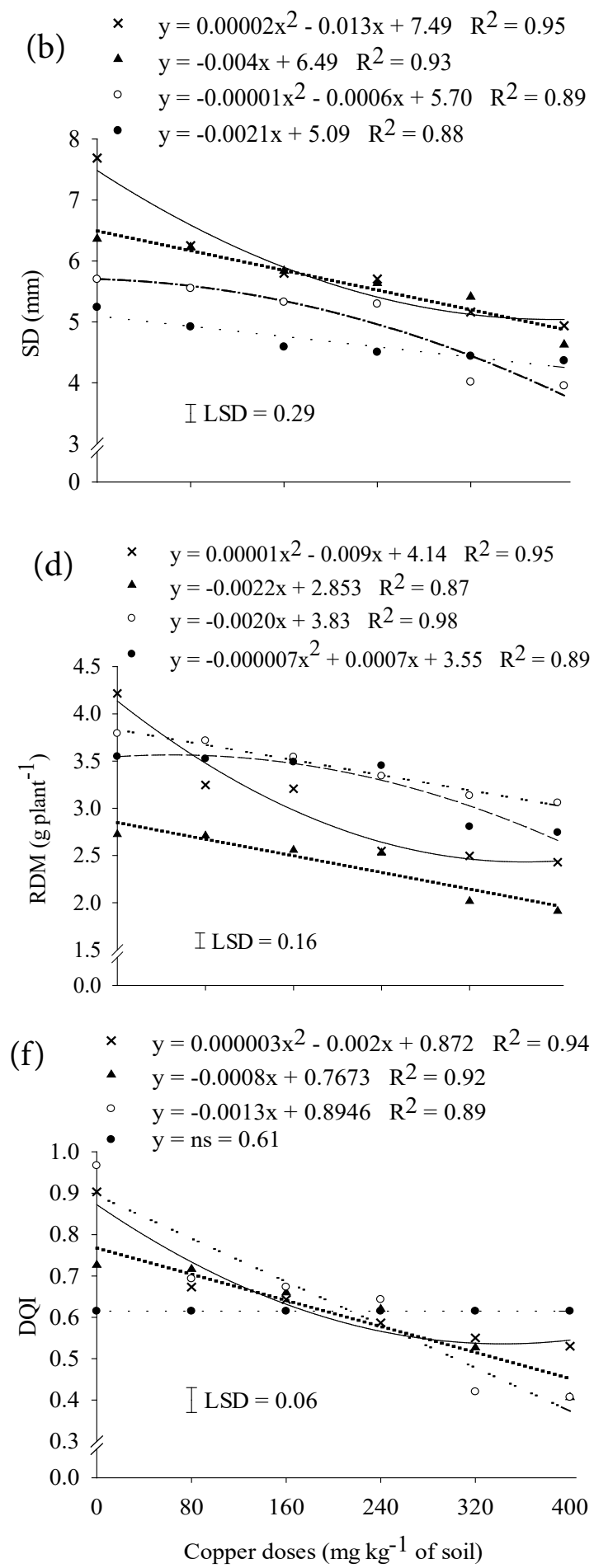

Figure 2. Height (a), stem diameter (b), shoot dry mass (c), root dry mass (d), specific surface area (e), and Dickson quality index (f) of C. citriodora, E. dunnii, E. grandis, and E. saligna seedlings in soil contaminated by copper.

SD: stem diameter; SDM: shoot dry mass; RDM: root dry mass; SSA: specific surface area; DQI: Dickson quality index; LSD: least significant difference; ns: not significant. 
The quadratic regression model for the $C$. citriodora seedlings was adjusted to the DQI, with an evident reduction of this index in the first $\mathrm{Cu}$ doses applied to the soil, as shown in Figure 2f. There was a linear reduction of $41.7 \%$ and $58.1 \%$ in the DQI at the maximum dose of the metal in the E. dunnii and E. grandis seedlings. In order to estimate DQI, morphological attributes that show seed vigor and quality are considered (Rossi et al., 2008). Thus, it was observed that the E. saligna seedling quality was not influenced by the $\mathrm{Cu}$ applied to the soil.

The Toi was linearly reduced by $\mathrm{Cu}$ applied to the soil, presenting values of 28 and $41 \%$ of $C$. citriodora and E. dunnii at the maximum dose of the metal applied to the soil, respectively, and induced a quadratic response with a maximum point at the estimated dose of 86.3 and $231 \mathrm{mg} \mathrm{kg}^{-1}$ for E. grandis and E. saligna, respectively, as shown in Figure 3. The tolerance ability of plants to heavy metals is because of the presence of mechanisms which enable them to survive in soils in which other plants would present too much toxicity to be tolerated (Macnair et al., 2000).

$\times \quad$ Corymbia citriodora

\ Eucalyptus dunnii

$\times \quad \mathrm{y}=-0.058 \mathrm{x}+83.87 \mathrm{R}^{2}=0.95$

- $\mathrm{y}=-0.083 \mathrm{x}+80.79 \quad \mathrm{R}^{2}=0.98$

- $\mathrm{y}=-0.0004 \mathrm{x}^{2}+0.069 \mathrm{x}+83.15 \mathrm{R}^{2}=0.85$

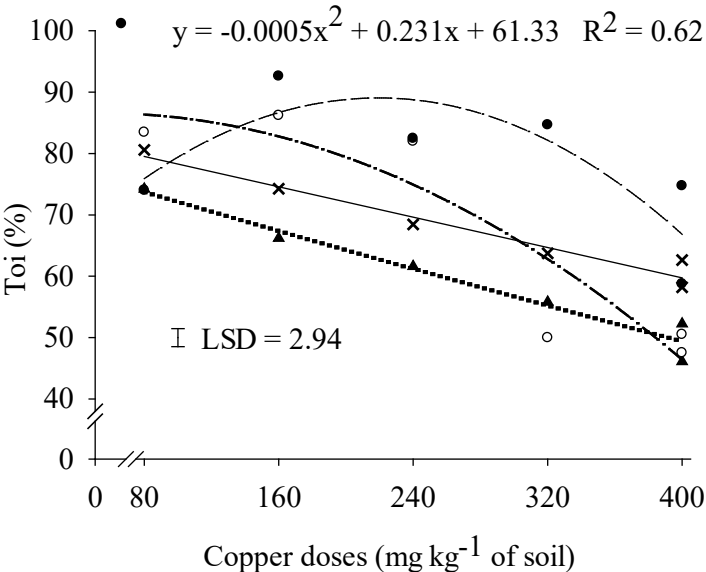

Figure 3. Regression equations for the tolerance index (Toi) of C. citriodora, E. dunnii, E. grandis, and E. saligna seedlings grown in soil contaminated by copper.

LSD: least significant difference.

Some plant species have developed tolerance or resistance to heavy metals because they present a complex mechanism of homeostasis that enables these plants to develop by controlling the absorption, accumulation, and translocation of metals in the plant (Santos et al., 2006). The ability of the plant to maintain higher levels of metals in the root system regarding the shoot indicates the presence of a separating mechanism of the metal, and consequent reduction of its translocation to the shoot (Accioly et al., 2004). In the classification scale according to the Toi, a species is considered tolerant when its Toi is higher than $60 \%$, moderate between 60 and $35 \%$, and sensitive when lower than $35 \%$ (Lux et al., 2004). According to the obtained data, the C. citriodora and E. saligna species were considered tolerant until the maximum studied dose, and the E. dunnii and E. grandis species up to the dose of $240 \mathrm{mg} \mathrm{kg}^{-1}$.

In general, the morphological variables of the different studied eucalyptus species were reduced. However, different responses by the species to the $\mathrm{Cu}$ levels added to the soil were observed, including (according to Toi) C. citriodora and $E$. saligna species being considered tolerant, even when $400 \mathrm{mg} \mathrm{Cu} \mathrm{kg}^{-1}$ of soil was used. This study shows that there are differences among plant species when submitted to high $\mathrm{Cu}$ doses, so that studies assessing the classification and selection of species which are capable of developing, tolerating, and decontaminating areas should be considered.

\section{CONCLUSION}

The implemented copper doses reduced the morphological variables of Eucalyptus grandis, E. saligna, E. dunnii, and Corymbia citriodora seedlings.

Eucalyptus saligna species had a higher tolerance index to the copper doses applied to the soil and could be considered for cultivation in areas contaminated by copper.

\section{ACKNOWLEDGEMENTS}

Coordenação de Aperfeiçoamento de Pessoal de Nível Superior (Capes).

\section{SUBMISSION STATUS}

Received: 4 Jan. 2018

Accepted: 30 June 2018

Associate editor: José Henrique Tertulino Rocha

(D) 0000-0002-7471-4191

\section{CORRESPONDENCE TO}

\section{Alex Negrini}

Universidade Federal de Santa Maria (UFSM), Linhas 7 de Setembro, s/n, BR 386, km 40, CEP 98400-000, Frederico Westphalen, RS, Brasil e-mail: alex.negrini@yahoo.com.br

\section{FINANCIAL SUPPORT}

Coordenação de Aperfeiçoamento de Pessoal de Nível Superior (Capes). 


\section{REFERENCES}

Accioly AMA, Siqueira JO, Curi N, Moreira FMS. Amenização do calcário na toxidez de zinco e cádmio para mudas de Eucalyptus camaldulensis cultivadas em solo contaminado. Revista Brasileira de Ciência do Solo 2004; 28(4): 775-783. 10.1590/S010006832004000400017

Andreazza R, Okeke BC, Lambais MR, Bortolon L, Melo GW, Camargo FA. Bacterial stimulation of copper phytoaccumulation by bioaugmentation with rhizosphere bacteria. Chemosphere 2010; 81(9): 1149-1154. 10.1016/j.chemosphere.2010.09.047

Andreazza R, Camargo FAO, Antoniolli ZI, Quadro MS, Barcelos AA. Biorremediação de áreas contaminadas com cobre. Revista de Ciências Agrárias 2013: 36(2): 127-136.

Chaignon V, Hinsinger PA. Biotest for evaluating for bioavailability to plants in a contaminated soil. Journal of Environment Quality 2003; 32(3): 824-833. 10.2134/jeq2003.8240

Conselho Nacional do Meio Ambiente - Conama. Resolução $\mathrm{n}^{\circ}$ 420, de 28 de dezembro de 2009. Diário Oficial da União [Internet], Brasília, DF (2009 Dec. 30) [cited 2017 Nov. 8]; Sec. 1: 81-84. Available from: https://bit.ly/2KbYnNC

De Marco R, Silva RF, Scheid DL, Da Ros CO, Silva VR. Amenizante Orgânico e Eucalyptus grandis para fitoestabilização de solo contaminado com cobre. Floresta e Ambiente 2017; 24: e00029315. $10.1590 / 2179-8087.029315$

Dghaim R, Al Khatib S, Rasool H, Ali Khan M. Determination of heavy metals concentration in traditional herbs commonly consumed in the United Arab Emirates. Journal of Environmental and Public Health 2015; 2015(4): 1-6. 10.1155/2015/973878

Dickson A, Leaf AL, Hosner JF. Quality appraisal of white spruce and white pine seedling stock in nurseries. Forestry Chronicle 1960; 36: 10-13.

Fundação Estadual de Meio Ambiente do Rio Grande do Sul Fepam. Portaria $n^{\circ}$ 85/2014. Dispõe sobre o estabelecimento de Valores de Referência de Qualidade (VQR) dos solos para nove elementos químicos naturalmente presentes nas diferentes províncias geomorfológicas/geológicas do estado do Rio Grande do Sul. Porto Alegre: Fepam; 2014.

Ferreira DF. SISVAR: Sistema de análise de variância. Versão 5.3. Lavras: UFLA; 2011.

Gonçalves JLM, Benedetti V. Nutrição e fertilização florestal. Piracicaba: IPEF; 2005.

Guo XY, Zuo YB, Wang BR, Li JM, Ma YB. Toxicity and accumulation of copper and nickel in maize plants cropped on calcareous and acidic field soils. Plant and Soil 2010; 333(1-2): 365-373. 10.1007/ s11104-010-0351-0

Kabata-Pendias A. Trace elements in soils and plants. 4th ed. London, Boca Raton: CRC Press; 2011.

Kukkola E, Rautio P, Huttunen S. Stress indications in copper-and nickel-exposed Scots pine seedlings. Environmental and Experimental Botany 2000; 43(3): 197-210. 10.1016/S0098-8472(99)00057-x

Lequeux H, Hermans C, Lutts S, Verbruggen, N. Response to copper excess in Arabidopsis thaliana: Impact on the root system architecture, hormone distribution, lignin accumulation and mineral profile. Plant Physiology and Biochemistry 2010; 48(8): 673-682. 10.1016/j.plaphy.2010.05.005
Lux A, Sottníková A, Opatrná J, Greger M. Differences in structure of adventitious roots in Salix clones with contrasting characteristics of cadmium accumulation and sensitivity. Physiologia Plantarum 2004; 120(4): 537-545. 10.1111/j.0031-9317.2004.0275.x

Macnair MR, Tilstone GH, Smith SE. The genetics of metal tolerance and accumulation in higher plants. In: Terry N, Banuelos G, editors. Phytoremediation of contaminated soil and water. Boca Raton: CRC Press; 2000. p. 235-250.

Magalhães MOL, Sobrinho NMBA, Santos FS, Mazur N. Potencial de duas espécies de eucalipto na fitoestabilização de solo contaminado com zinco. Revista Ciência Agronômica 2011; 42(3): 805-812. 10.1590/S1806-66902011000300029

Mann SS, Ritchie GSP. The influence of $\mathrm{pH}$ on the forms of cadmium in four west Australian soils. Australian Journal of Soil Research 1993; 31(3): 255-270. 10.1071/SR9930255

Rossi VL, Amarante CVT, Fleig FD. Crescimento e qualidade de mudas de Pinus taeda L. submetidas à poda química de raízes. Revista Ciência Florestal 2008; 18(4): 435-442. 10.5902/19805098427

Santos FS, Amaral Sobrinho NMB, Mazur M. Mecanismos de tolerância de plantas a metais pesados. In: Fernandes MS, editor. Nutrição mineral de plantas. Viçosa: SBCS; 2006. p. 420-432.

Santos GCG, Rodella AA, Abreu CA, Coscione AR. Vegetable species for phytoextraction of boron, copper, lead, manganese and zinc from contaminated soil. Scientia Agricola 2010; 67(6): 713-719. 10.1590/S0103-90162010000600014

Silva RF, Da Ros CO, Dellai A, Grolli AL, Scheid DL, Viel P. Interferência de doses de cobre no crescimento e na qualidade de mudas de Bauhinia forficata Link, Pterogyne nitens Tul e Enterolobium contortisiliquum Vell. Ciência Florestal 2016; 26(2): 647-655. 10.5902/1980509822764

Silva RF, Saidelles FLF, Silva AS, Bolzan JS. Influência da contaminação do solo por cobre no crescimento e qualidade de mudas de açoita-cavalo (Luehea divaricata Mart. Zucc.) e aroeiravermelha (Schinus therebinthifolius Raddi). Ciência Florestal 2011; 21(1): 111-118. 10.5902/198050982753

Souza, EP, Silva IF, Ferreira LE. Mecanismos de tolerância a estresses por metais pesados em plantas. Revista Brasileira de Agrociência 2011; 17(2): 167-173. 10.18539/cast.v17i2.2046

Taiz L, Zeiger E, Møller IM, Murphy A. Fisiologia vegetal. 6th ed. Porto Alegre: Artmed; 2017.

Tedesco MJ, Gianello C, Bissani CA, Bohnen H, Volkweiss SJ. Análise de solo, plantas e outros materiais. Porto Alegre: Universidade Federal do Rio Grande do Sul; 1995.

Tennant DA. Test of a modified line intersect method of estimating root length. Journal of Ecology 1975; 63(3): 995-1001. $10.2307 / 2258617$

United States Environmental Protection Agency - USEPA. Method 3050 B: Acid digestion of sediments, sludges, and soils. Washington: USEPA; 1996

Wilkins DA. The measurement of tolerance to edaphic factors by means of root grown. The New Phytoogist 1978; 80(3): 623-633. 10.1111/j.1469-8137.1978.tb01595.x

Yruela I. Copper in plants: acquisition, transport and interactions. Functional Plant Biology 2009; 36(5): 409-430. 10.1071/FP08288 